\title{
RHEUMATOID DISEASE IN THE LARYNX AND LUNG
}

\author{
BY \\ G. A. GRESHAM AND T. D. KELLAWAY \\ From the Department of Pathology, University of Cambridge
}

Visceral manifestations of rheumatoid disease have recently received considerable attention. Lesions in the larynx, lung, and heart are of clinical importance. The object of this paper is to report one example of severe laryngeal involvement and another with unusual pulmonary lesions. The histochemical properties of these lesions are compared with those of a histologically typical rheumatoid nodule.

\section{Case Reports}

\section{Case 1. Rheumatoid Disease of the Larynx}

A woman aged 32 was admitted to hospital on February 10,1957, with dyspnoea which had been present for 3 weeks and had become worse in the last 3 days. She had an unproductive cough. A similar attack, lasting one week, had occurred 6 weeks before admission.

Rheumatoid arthritis had been present since 1948; an arthrodesis of the left knee was done in 1951 because of severe flexion contracture. At this time there was facial hirsutes and a palpable spleen; the blood haemoglobin was $11 \cdot 1 \mathrm{~g}$. per $100 \mathrm{ml}$., the lowest white blood count was 3,700 per cu.mm. with 65 per cent. polymorphonuclear neutrophil leucocytes, and the erythrocyte sedimentation rate (Wintrobe) was $30 \mathrm{~mm}$. in the first hour (corrected).

At the final admission she was thin, pale, and slightly cyanosed. Breathing was noisy and laboured. There was little lateral movement of the chest; breathing was largely accomplished by the accessory muscles of respiration. Laryngoscopy showed adduction of both cords: the left did not move and there was limitation of adduction on the right side. The interarytenoid region was oedematous. Examination of the lungs revealed diffusely scattered inspiratory and expiratory rhonchi. The respiratory rate was 40 per min., pulse rate 120 per min., temperature $99^{\circ} \mathrm{F}$., and blood pressure $130 / 90 \mathrm{~mm}$. Hg.

The patient was placed in a steam tent, but died suddenly 3 hours after admission. A tracheostomy was not made.

She had been treated with cortisone in hospital in 1951, and had had cortisone and Neomycin ointment to the eye a few months before death. During the last 2 days of life she was treated with Achromycin.

Necropsy.-The soft tissues of the larynx were oedematous but the glottis was patent. The mucosa of the larynx and trachea was yellow-red and covered by a small quantity of frothy fluid. The left vocal cord was swollen and shortened; the space between it and the vocal fold was reduced so that the orifice of the sinus of the larynx was occluded. The changes in the right cord were similar but less severe. The perichondrium of the cricoid stripped easily to reveal a median posterior necrotic defect of cartilage, about $0.4 \mathrm{~cm}$. in diameter.

The lungs were firm and oedematous and contained areas of consolidation in the lower lobes. Fibrous adhesions obliterated both pleural sacs. The heart showed a moderate degree of right ventricular hypertrophy; the atria, valves, left ventricle, and coronary arteries showed no important abnormality.

The spleen weighed $518 \mathrm{~g}$. and had a dark purple-red cut surface in which Malpighian bodies were conspicuous. There was moderate enlargement of cervical, axillary, mediastinal, abdominal, and inguinal lymph nodes. A large grey-brown thymus was present ( $38 \mathrm{~g}$.).

The hip joints, right knee, ankles, and right elbow were ankylosed; there was an arthrodesis of the left knee. The adjacent muscles were conspicuously wasted. The proximal interphalangeal joints showed characteristic "spindling" deformity; the fingers were deviated to the ulnar side. The wrist joints were swollen.

The body weighed $38 \mathrm{~kg}$. and measured $160 \times 38 \mathrm{~cm}$ The breasts were small. Sparse long hairs were present on the chin and upper lip; axillary and pubic hair was of normal distribution.

Histological Examination.-The larynx was hemisected longitudinally. Serial sections were made of the right half (Fig. 1, opposite) and also of a block taken from the left side through the full thickness of the posterior half of the vestibule of the larynx. This block was intended to include the left crico-arytenoid joint.

The right crico-arytenoid joint contained a few flakes of fibrin (Fig. 2, opposite) and a fold of synovium. Foci of granulation tissue in places replaced the lining of the joint, and adjacent areas of cartilage showed areas of bone absorption and also a few small areas of deposition of newly-formed woven bone.

Sections of the left side of the larynx (Fig. 3, opposite) did not reveal the arytenoid cartilage which had, apparently, been replaced by a dense chronic inflammatory infiltrate containing numerous plasma cells, lymphocytes, histiocytes, fibroblasts, scanty neutrophil polymorphonuclear leucocytes, and occasional giant cells. 


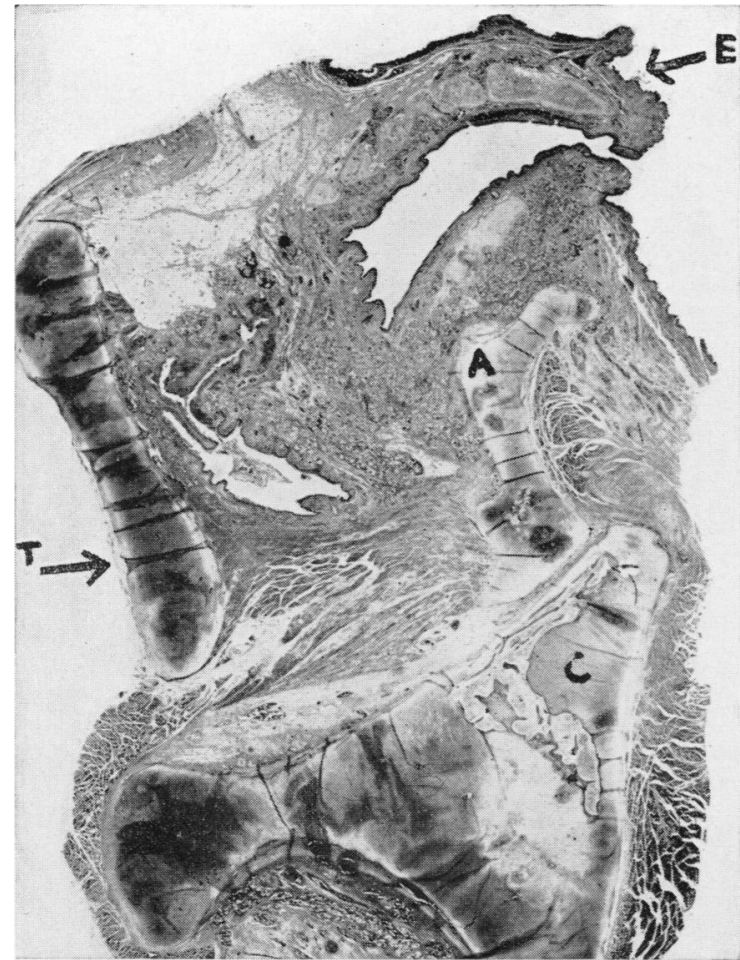

Fig. 1.-Longitudinal section of right side of larynx (Case 1), showing infiltration of aryepiglottic fold and relative positions of arytenoid (A) and cricoid $(C)$ cartilages. ( $E=$ epiglottis, $T=$ thyroid cartilage.) Haematoxylin and eosin. $\times 2 \cdot 5$

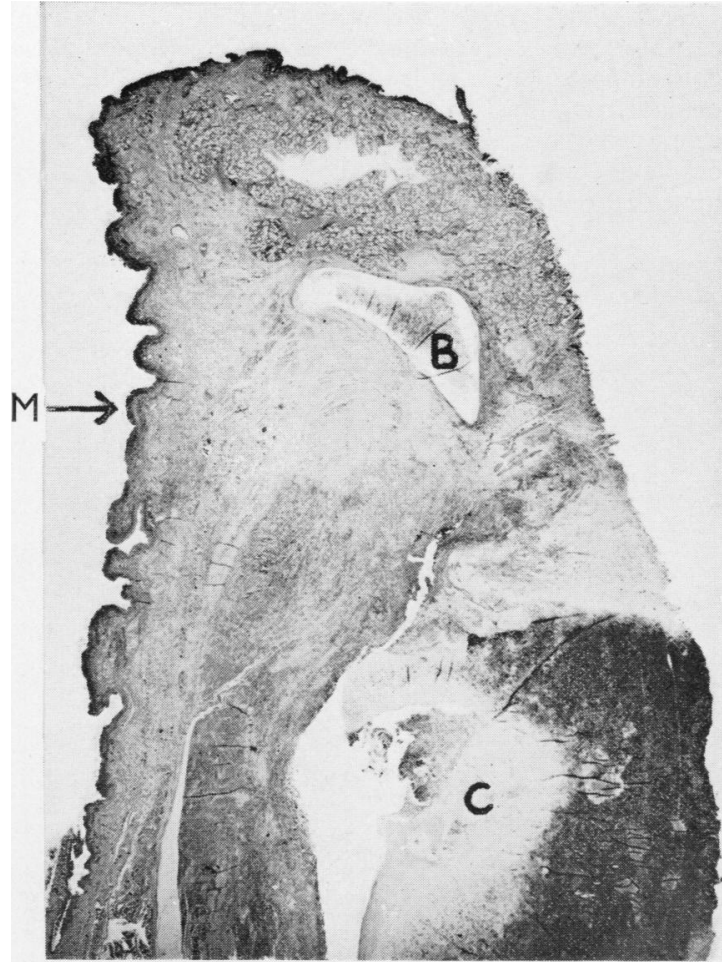

Fig. 3.-Longitudinal section of postero-lateral wall of laryngeal vestibule (Case 1), showing corniculate (B) and cricoid (C) cartilages, oesophageal mucosa (M), and heavy inflammatory infiltrate around posterior necrotic defect in cricoid. Haematoxylin and eosin. $\times 3.5$.

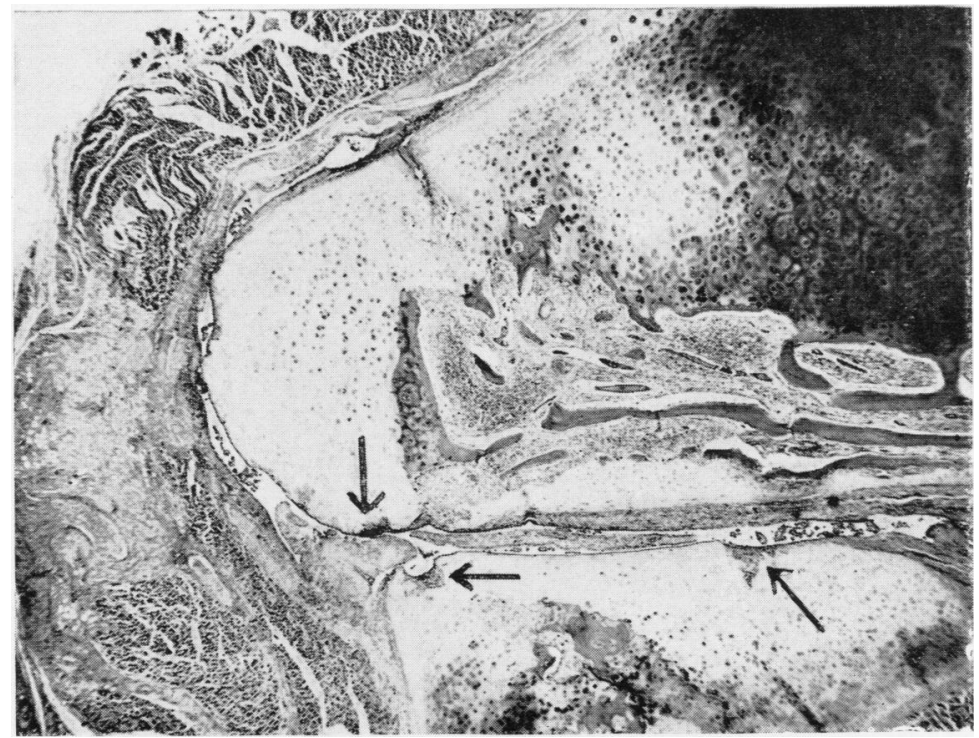

Fig. 2.-Right crico-arytenoid joint (Case 1), showing flakes of fibrin and synovial folds in joint space and granulation tissue (arrowed) invading cartilage. Haematoxylin and eosin. $\times 17$ 
This exudate extended around the adjacent cricoid cartilage, which was invaded by similar granulation tissue containing small islands of cartilage (Fig. 4) clearly demonstrated by its metachromatic staining with 1 per cent. toluidine blue. A small area of the adjacent cartilage was necrotic. The corniculate cartilage appeared normal.

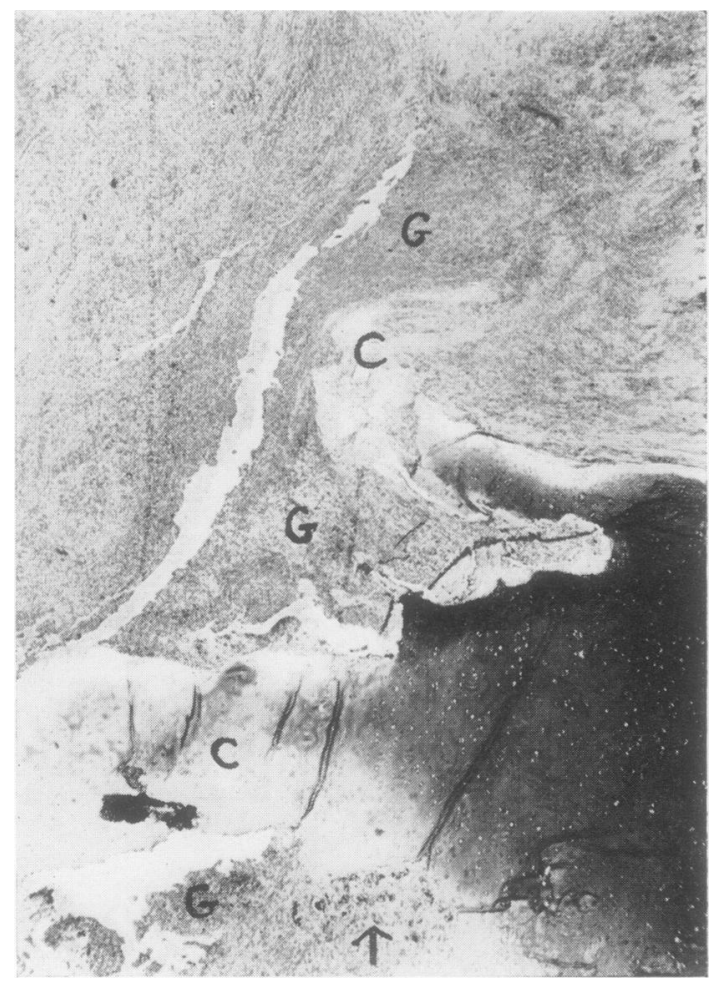

Fig. 4.-Case 1, postero-superior edge of cricoid cartilage (C), showing invasion of cartilage by granulation tissue $(G)$, with isolated islands of cartilage (arrowed). Toluidine blue. $\times 16$.

The inflammatory infiltrate on both sides of the larynx extended from the epiglottis to the origin of the trachea, involving all the soft tissues including the pharyngooesophageal mucous membrane. The infiltrate was most severe around the cricoid cartilage on the left, resulting in considerable damage to the voluntary muscles, many of the fibres of which were represented by giant cells (Fig. 5). Ill-defined, brightly eosinophilic granular areas with the staining properties of fibrinoid were present in this region.

The spaces between the trabeculae in the ossified areas of the arytenoid and cricoid cartilages were filled with vascular connective tissue containing plasma cells and lymphocytes.

Areas of recent bronchopneumonia were present in sections of lung, together with a severe degree of oedema and areas of intra-alveolar haemorrhage. Many bronchioles were surrounded by a slight chronic inflammatory

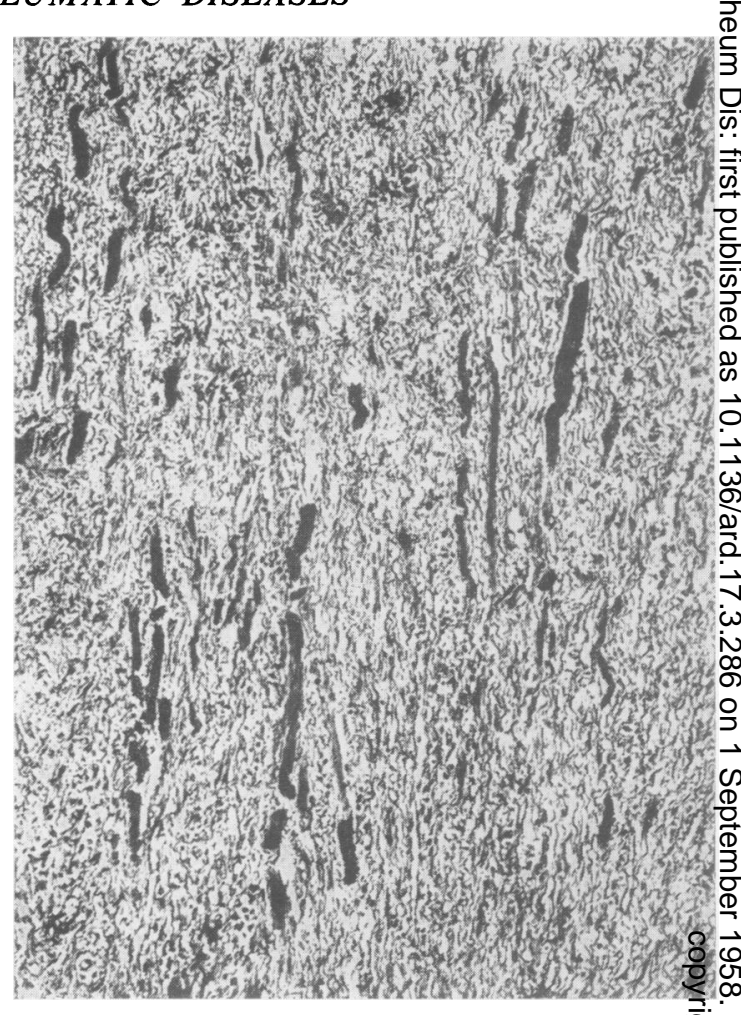

Fig. 5.-Left side of larynx, showing destruction of voluntary muşiळ (Case 1). Muscle fibres black. Mallory's phosphotungstic ąif haematoxylin. $\times 90$.

cell exudate including occasional foreign body giant cells:

In the heart small perivascular foci of lymphocytes were present in the ventricular septum. Foci of lympho $\overrightarrow{\vec{B}}$ cytes and plasma cells were found in sections of skeletas muscle.

Case 2. Cardiac and Pulmonary "Rheumatoid Disease"

A man aged 57 was brought in dead, having collapsed one hour before whilst riding on a bus. He had recentlyo suffered pain in the chest on exertion. Rheumatoid arthritis had been present for 21 years. He had last seer his doctor 5 years before, and had not apparently evero been treated with cortisone.

Necropsy.-A severe degree of rheumatoid arthritis? was present in both hands and wrists. The forearms were wasted and both elbow joints swollen. A subcutaneous node $(2 \mathrm{~cm}$. diameter) was found over the right olecranon process. Other joints were involved to a less severe degree.

The aortic valve was incompetent, the free margins of the cusps being thickened and fused at the commissures (Fig. 6, opposite); there was no calcification of the valve cusps. The left ventricle was moderately dilated an\& hypertrophied (the heart weight $480 \mathrm{~g}$.).

The lungs were emphysematous and contained diffuse? tiny subpleural cysts in all lobes (Fig. 7, opposite) 0 


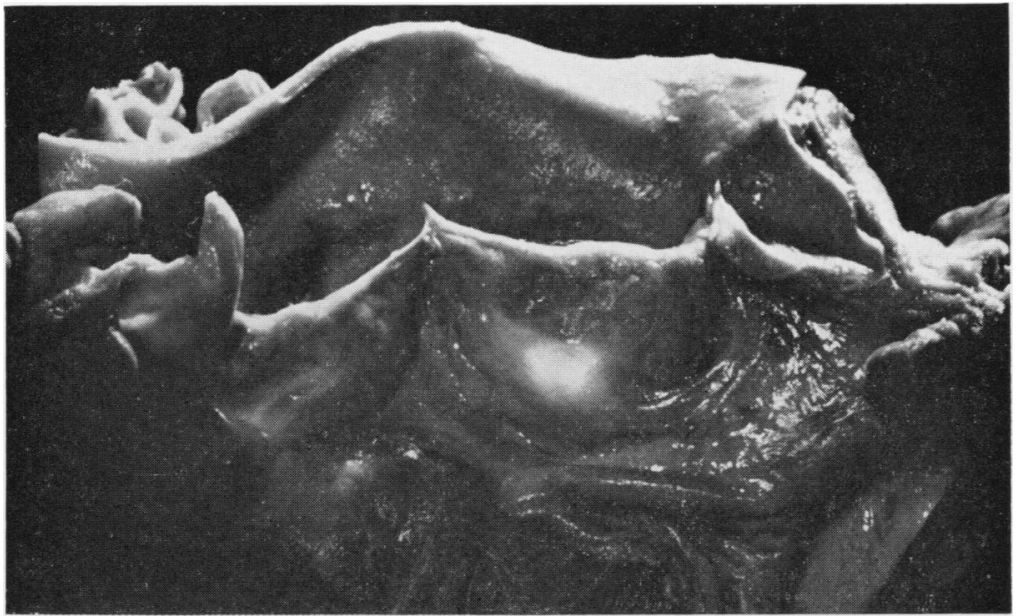

Fig. 6.-Aortic valve (Case 2), showing thick free borders of cusps and commissural fusion.

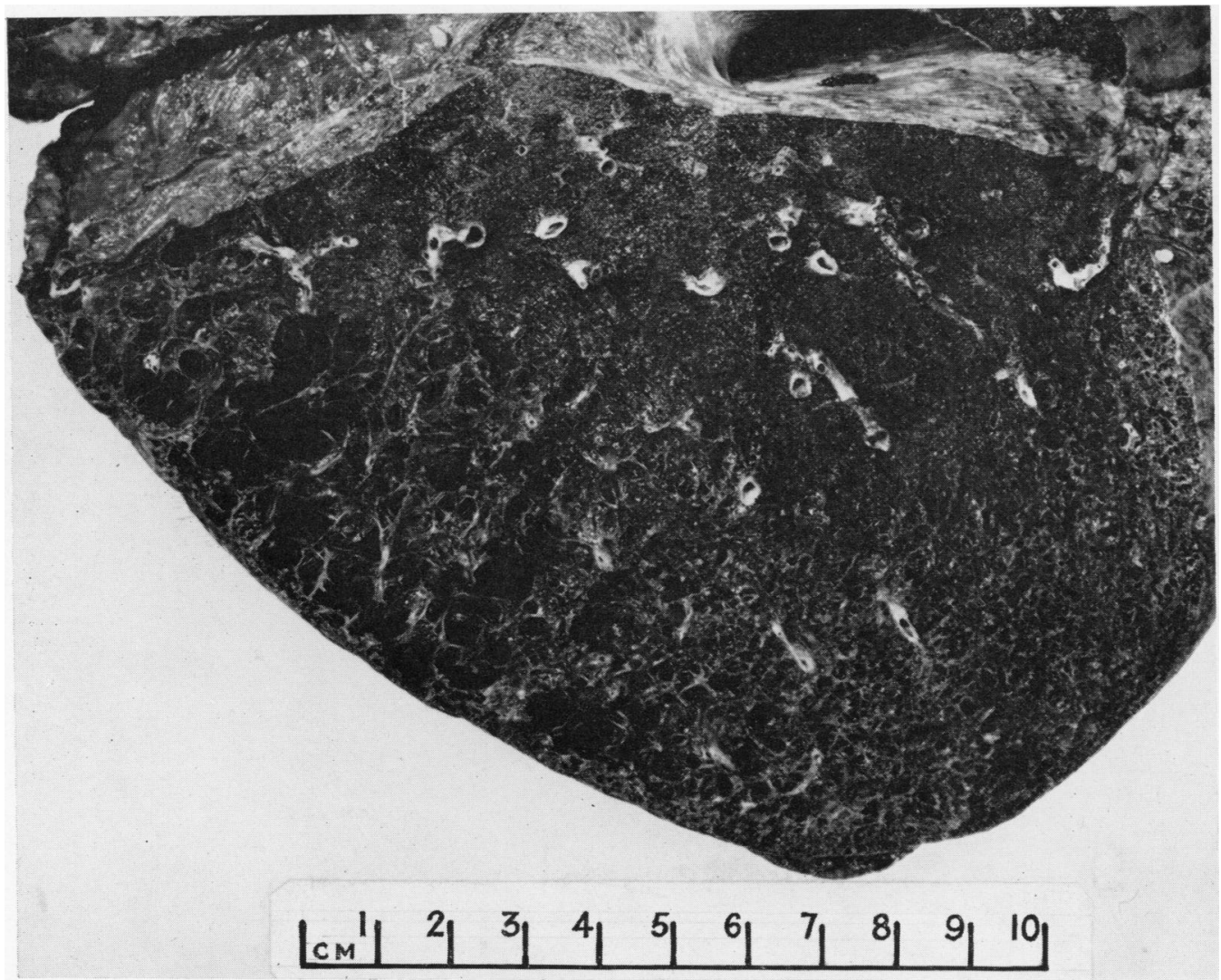

Fig. 7.-Subpleural pulmonary cysts (Case 2). 


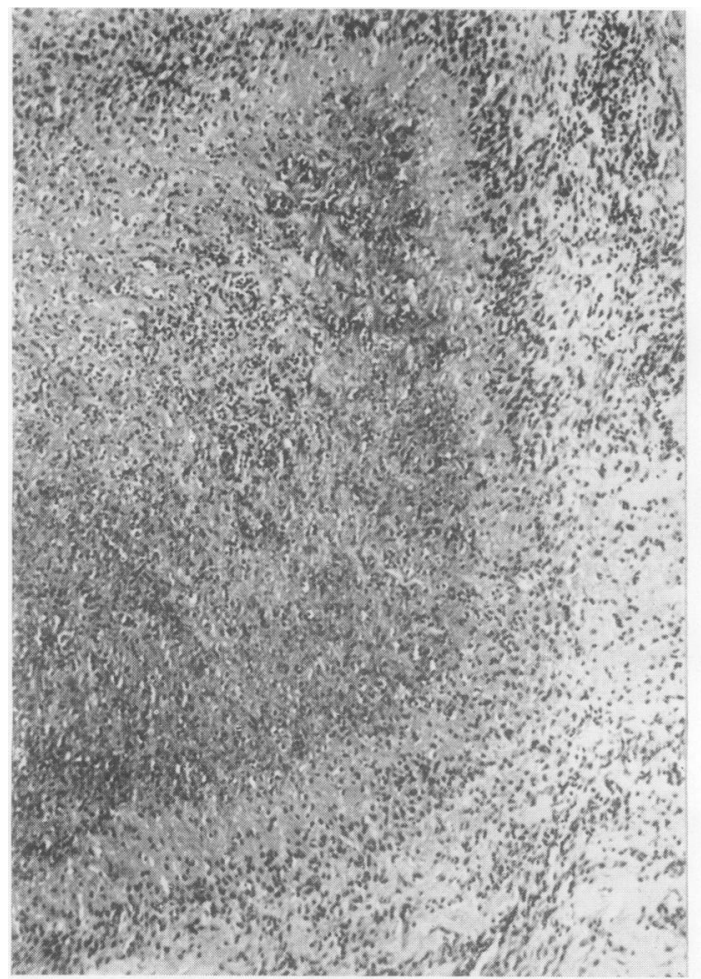

Fig. 8.-Palisades of histiocytes in subcutaneous node (Case 2). Haematoxylin and eosin. $\times 75$
The spleen weighed $230 \mathrm{~g}$. Lymph nodes were en larged in the neck, mediastinum, axillae, abdomen, and groins. Other organs showed no important abnormality.

Histological Examination.-A section of the subcutaneous node showed the typical appearance of rheumatoid disease: areas of necrosis containing fibrinoid material were surrounded by palisades of histiocytes (Fig. 8). Similar nodules were present in a section of lung taken』 from the left upper lobe (Fig. 9). The cysts in the lung were lined by connective tissue containing conspicuous groups of lymphocytes and smooth muscle; most had no. epithelial lining. They were probably derived from $\overrightarrow{ }$ alveolar ducts (Cunningham and Parkinson, 1950). It was not possible to determine whether the cysts were derived by granulomatous destruction of the lung tissue because "active" rheumatoid lesions were $\vec{V}$ scanty.

Superficial fibrinoid necrosis bordered by palisadedi histiocytes was present in the section of aortic valve (Fig. 10).

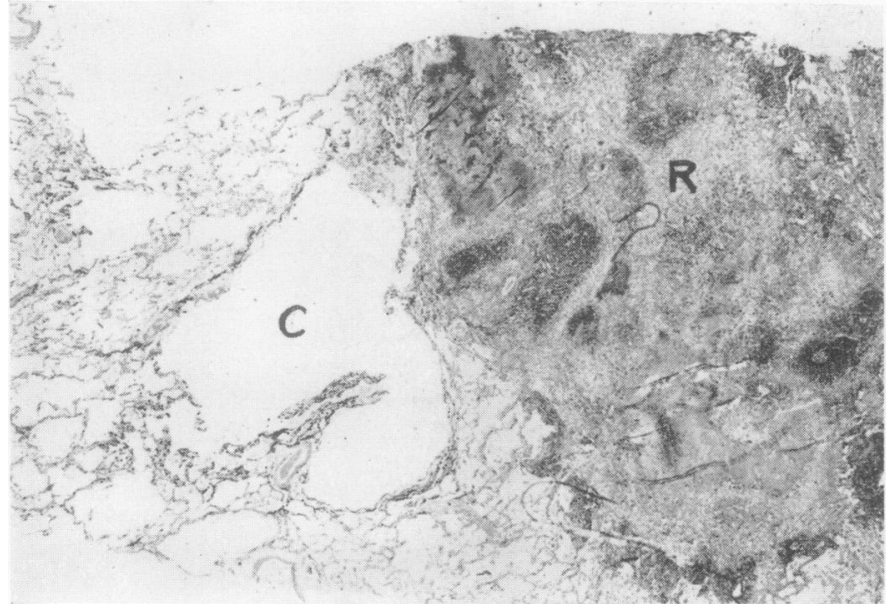

Fig. 10.-Rheumatoid granuloma ( $R$ ), with adjacent cyst $(C)$ in lung (Case 2). Haematoxylin and eosin. $\times 9$.

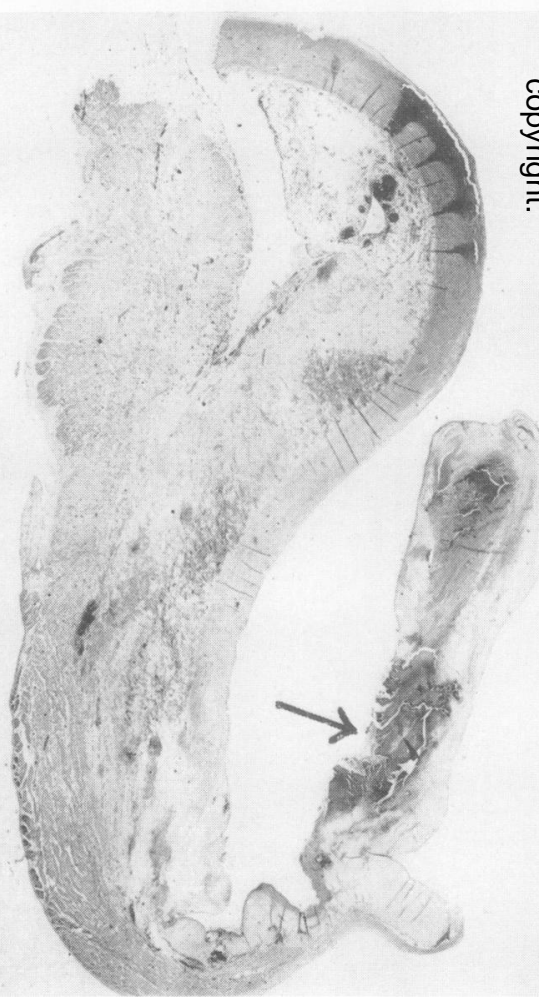

Fig. 9.-Aortic valve (Case 2), showing "rheumatoid lesion" (arrowed) on inner surface of cusp. Haematoxylin and eosin. $\times 3$. 


\section{Histochemical Findings in Cases 1 and 2}

Comparison of the well-defined nodular lesions in Case 2 with the diffuse areas of fibrinoid material in the larynx was difficult. Nevertheless the histochemical findings were similar. The lesions contained abundant protein as shown by the tetrazo method (Danielli, 1947) and were much more intensely stained than the surrounding tissues. Ribonucleic acid and deoxyribonucleic acid were demonstrated in the lesions by pyronin and the Feulgen method respectively. The Feulgen-positive material was present mainly as nuclear remnants in the peripheral zone of inflammatory cells of the rheumatoid lesion (Case 2).

Fibrinoid material was P.A.S. positive. Permanganate paraldehyde fuchsin (Gomori, 1950) did not stain the fibrinoid material, but faint staining was obtained with sudan black.

The histochemical findings show that the lesions in both cases contain similar material which would appear to be a muco- or glyco-protein, probably derived from dead cells. The peripheral Feulgenpositive fragments in the lesions in Case 2 are most likely to be nuclear remnants.

\section{Discussion}

Although rheumatoid disease has previously been described in the larynx, the precise site of the lesion and its histological appearance has not been clearly defined. Some authors (Montgomery, Perone, and Schall, 1955; Pearson, 1957; Copeman, 1957; Baker and Bywaters, 1957) regard the crico-arytenoid joint as the principal site of involvement. However Megighian (1955) has described diffuse degeneration of laryngeal, nasal, and auricular cartilage, with adjacent fibrinoid necrosis in biopsy specimens from a case of rheumatoid arthritis. Localized nodules of rheumatoid disease have not been described in the larynx itself though nodular involvement of the epiglottis has been reported (Raven, Weber, and Price, 1948).

The lesion in Case 1 has some features in common with that described by Megighian. There was a diffuse infiltration of laryngeal tissues by chronic inflammatory cells with some fibrinoid necrosis. Associated with this was destruction of cartilage, clearly demonstrable in the cricoid; the left arytenoid had apparently disappeared.

Fragments of fibrinoid material were present in the cricoarytenoid joint space of the opposite side. The joint was, however, relatively unaffected as compared with other parts of the larynx which showed a severe degree of inflammation of the soft tissues and considerable muscle destruction.
Laryngeal obstruction which necessitates tracheostomy is occasionally seen in patients with rheumatoid arthritis, and has been attributed to arthritis of the cricoarytenoid joint. In Case 1, the laryngeal obstruction could be explained by muscle destruction alone. Complete paralysis of the left vocal cord was probably due to the severe degree of inflammation and destruction of the arytenoid cartilage rather than to joint involvement.

Text-books of laryngology describe chronic hyperplastic laryngitis (Ellis, 1951; Scott-Brown, 1952; Thomson and Negus, 1955), considering "rheumatic disease" as one of many causative factors. The laryngeal lesion in Case 1 may be described as hyperplastic laryngitis. The diffuse chronic inflammatory infiltration of the larynx associated with rheumatoid arthritis, and the presence of material similar histochemically to that found in the rheumatoid nodule, strongly suggest that the laryngeal lesion itself is rheumatoid in origin. On the other hand, the fibrinoid degeneration may be the response of a rheumatoid patient to non-specific chronic laryngitis. It is possible that the diffuse inflammatory lesion is a precursor of rheumatoid crico-arytenoiditis, but the evidence from this case does not support such a view.

The clinical diagnosis of rheumatoid arthritis of the crico-arytenoid joint has been based on the following findings: local tenderness between the thyroid and cricoid cartilages, a variable amount of oedema and redness in the arytenoid and prearytenoid area, and pain on manipulation of the arytenoids (Montgomery and others, 1955; Copeman, 1957; Baker and Bywaters, 1957). It is probable that similar signs would have been demonstrable in Case 1.

Sections of rheumatoid and normal larynx demonstrated the lateral position of the joint space and the anterior position of the arytenoid cartilage. Failure to appreciate this anatomical feature may lead to the erroneous histological diagnosis of forward subluxation of the arytenoid.

Specific rheumatoid lesions in the heart valves (Baggenstoss and Rosenberg, 1941, 1944; Gruenwald, 1948; Bywaters, 1950; Bevans, Nadell, Demartini, and Ragan, 1954; Ellman, Cudkowicz, and Elwood, 1954; Valaitis, Pilz, and Montgomery, 1957), nodular lesions in the lung (Raven and others, 1948; Bevans and others, 1954; Christie, 1954; Ellman and others, 1954; Maher, 1954; Skogrand, 1956), nodular lesions in the lung in association with pneumoconiosis (Gough, Rivers, and Seal, 1955) and cystic lesions in the lung (Hart and Mackenzie, 1955; Dixon and Ball, 1957) are well-recognized features of rheumatoid disease and serve to empha- 
size the systemic nature of the disorder. The association of pulmonary cystic changes with "rheumatoid nodules" has not, so far as we are aware, been reported.

\section{Summary}

(1) Extensive inflammatory infiltration of the larynx, with destruction of cartilage, leading to death from respiratory obstruction, is described in a patient with rheumatoid arthritis.

(2) The diffuse nature of the rheumatoid lesion in the larynx is emphasized.

(3) The unusual association of cystic and nodular "rheumatoid" lesions in the lung are reported in another case.

(4) The histochemical features of lesions in the larynx and lung are found to be similar to those in a juxta-articular "rheumatoid nodule".

We are grateful to Dr. A. M. Barrett for his advice and criticism, and to Dr. L. C. Martin and H.M. Coroner of the City of Cambridge for permission to publish these case reports. Mr. S. W. Patman prepared the photomicrographs.

\section{REFERENCES}

Baggenstoss, A. H., and Rosenberg, E. F. (1941). Arch. intern. Med. 67,241

- 67, (1944). Arch. Path. Lab. Med., 37, 54

Baker, O. A., and Bywaters, E. G. L. (1957). Brit. med. J., 1, 1400.

Bevans, M., Nadell, J., Demartini, F. E., and Ragan, C. (1954). Amer. J. Med., 16, 197

Bywaters, E. G. L. (1950). Brit. Heart J., 12, 101.

Christie, G. S. (1954). Aust. Ann. Med., 3, 49 (quoted at length by Rubin, 1955).

Copeman, W. S. C. (1957). Brit, med. J., 1, 1398.

Cunningham, G. J., and Parkinson, T. (1950). Thorax, 5, 43.

Danielli, J. F. (1947). Symp. Soc. exp. Biol., 1, 101.

Dixon, A. St. J., and Ball, J. (1957). Ann, rheum. Dis., 16, 241

Ellis, M. (1951-52) In "British Encyclopaedia of Medical Practice" 2nd ed., vol. 7 , p. 629. Ellman, P., Cudkowicz, L., and Elwood, J. S. (1954). J. clin. Path.,
Gomori, G. (1950), Amer. J. clin. Path, 20, 665.

Gough, J., Rivers, D., and Seal, R. M. E. (1955). Thorax, 10, 9. Gruenwald, P. (1948). Arch. Path. (Chicago), 46, 59.

Hart, F. Dudley, and Mackenzie, D. H. (1955). Brit. med. J., 2, 890.

Maher, J. A. (1954). A.M.A. Arch. Path., 58, 354.

Megighian, D. (1955). Arch. ital. Otol., 66, Suppl. 26, p. 65.

Montgomery, W. W.. Perone, P. M., and Schall, L. A. (1955). Ann. Otol. (St. Loutis), 64, 1025

Pearson, J. E. G. (1957). Brit. med. J., 1, 1047.

Raven, R. W., Weber, F. Parkes, and Price, L. W. (1948). Ann. rheum. Dis., 7, 63 .

Rubin, E. H. (1955). Amer. J. Med., 19, 569.

rown, W. G. (1952) "Diseases of the vol. 1, p. 615. Butterworth, London.

Skogrand, A. (1956). Acta rheum. scand 2, 17.

Thomson, St. C. (1955). "Diseases of the Nose and Throat", 6th ed., 568, 703. Cassell, London.

Valaitis, J., Pilz, C. G., and Montgomery, M. M. (1957). A.M.A. Arch. Path., 63, 207.

Maladie rhumatismale du larynx et des poumons

RÉSUMÉ

(1) On décrit un cas d'arthrite rhumatismale accompagnée d'une infiltration inflammatoire étendue dularynx, avec destruction du cartilage, menant à la mort. due à l'obstruction respiratoire.

(2) On souligne la nature diffuse de la lésion rhumatis- $\infty$ male du larynx.

(3) On rapporte un autre cas, peu commun, de lésions음 cystiques et nodulaires "rhumatismales" dans le poumon. $\rightarrow$

(4) On trouve que les caractères histo-chimiques descs lésions laryngées et pulmonaires sont similaires à celles $\mathbb{D}$ des "nodules rhumatismaux" juxta-articulaires.

Enfermedad reumatoide en la laringe y en el pulmón Sumario

(1) Se describe un caso de artritis reumatoide asocia a una infiltración inflamatoria extensa de la laringe, c®o $\infty$ destrucción del cartilago, conduciendo a la muerte par obstrucción respiratoria.

(2) Se subraya la naturaleza difusa de la lesiơn reumatoide de la laringe.

(3) Se relata un otro caso, poco común, de lesiones císticas y nodulares "reumatoides" en el pulmón.

(4) Los caracteres histo-químicos de las lesiones laríngeas y pulmonares reveláronse similares a las de los $\overrightarrow{\overrightarrow{0}}$ "nódulos reumatoides" yuxta-articulares. 